\title{
Changes ahead for US policy on biotechnology regulations
}

Washington

THE White House Office of Science and Technology Policy (OSTP) is at the centre of a policy struggle over the control of federal oversight of biotechnology.

There are signs that OSTP is seeking to wrest control of oversight from the Biotechnology Science Coordinating Committee (BSCC), and to expand its charter to include jurisdiction of federal efforts to map and sequence the human genome and human gene therapy.

In a bizarre twist, press reports surfaced last week that BSCC chairman David Kingsbury is under investigation by the Justice Department for possible conflict of interest arising from his association with a British biotechnology company.

BSCC was established by former White House science adviser George Keyworth II in 1985 as part of the Federal Coordinating Council for Science, Engineering and Technology. It is made up of senior officials of the federal agencies involved in biotechnology research and product regulation.

\section{What future now for Japanese biotechnology research?}

\section{Osaka}

WHERE is biotechnology headed in Japan? The BIO87 conference held in Osaka last week gives some indication.

The early days, when giant chemical, distilling and pharmaceutical companies paid high prices to license frontier technology from small US venture concerns, are now long gone. So is the fad for interferon which preceded the rush to produce tumour necrosis factor and colony stimulating factor.

According to Mitsuru Miyata, editor of Nikkei Biotech, who spoke at the conference, there is a growing belief that the future of biotechnology lies not in the mass-production of proteins but in gaining knowledge of the structures and functions of the molecules, for example, through protein engineering. And about 20 biotechnology companies, including the big five' (Kyowa Hakko Kogyo, Takeda Chemical Industries, Toray Industries, Mitsubishi Chemical Industries and Ajinomoto) and Toa Nenryo Kogyo, an oil-refining company, will open the Protein Engineering Research Institute in Osaka next autumn (see Nature 325, 651; 1987).

But such research and development will have a very long lead time, probably of more than a decade, and in the meantime companies are promoting small-scale enterprises using existing technology. Already cell-fusion technology is aiding the production of sake and orchids are being propagated using tissue culture. Japan's 47 prefectures have more than 100 biotechnology promotion centres and biotechnology companies are establishing links with them and with agricultural cooperatives to disseminate knowledge.

Plant biotechnology featured prominently in the conference. Building on successes in growing rice from protoplasts (Nature 321, 639; 1986) Dr K. Shimamoto of Plantech Research Institute has succeeded in growing 250 hybrid plants created by electro-fusion of protoplasts of cultivated and wild rice. All have grown to maturity and some have started to flower. The development will give rise to the virtually untapped genetic variability in the ten species of wild rice.

The Ministry of Agriculture, Forestry and Fisheries is also showing keen interest in rice biotechnology, and 70 million $(\$ 500,000)$ has been allocated for a feasibility study for full sequencing of the chromosomal DNA of rice. But, according to Miyata, the ministry sees many technical difficulties ahead and may favour a simpler mapping project. The ministry has already paid out $¥ 290$ million (\$2 million) to the United States for the genome map of the tomato plant, and this will be used with conventional technology to create new nutritious tomatoes.

Japan has gone a long way towards catching up the West in biotechnology. Technology is now beginning to flow the other way; for example, Genentech has signed a five-year agreement with Mitsubishi Chemical Industries for rights to Mitsubishi's biotech pharmaceuticals.

So will the future see trade disputes erupting between Japan and the United States over biotechnology? Ronald Cape, chairman of Cetus corporation, hopes not. He says that the lead times between invention and marketing of biotechnology products is often long compared with other high-technology goods, partly because of problems over patenting and government environmental and health regulations. And he believes this delay will provide opportunities for Japan-US cooperation in research and development. And as a step in that direction he proposed a "Harmony Fellowship" scheme for international exchange of late-postdoctoral fellows with initial funding from the private sector.
Kingsbury, assistant director of the National Science Foundation (NSF), and director of the division of biological, behavioural and social sciences, has chaired BSCC since its inception.

In June 1986, the working group promulgated the coordinated framework for regulation of biotechnology, an attempt to rationalize the interlocking jurisdictions of federal agencies and to establish uniform policy (see Nature 321, 458; 1987).

Kingsbury and BSCC have received mixed reviews for their efforts. The biotechnology industry has been generally pleased, but critics say the framework has failed to achieve its goal of coordination, and has left far too many loose ends, allowing potentially risky experiments to slip through regulatory cracks.

Kingsbury has been an energetic champion of the framework and BSCC. $\mathrm{He}$ also has sought to expand the role of the Domestic Policy Council working group on biotechnology. Earlier this year he established a task force that was intended to oversee federal involvement to map and sequence the human genome (see Nature 325, 651; 1987).

But BSCC's charter was written with a sunset clause that puts it out of existence at the end of this month unless action is taken to renew it. OSTP has been seeking input from membership of BSCC, as well as other government agencies, about how a new body should be constituted. OSTP spokesperson Mary English says some decisions about the future of BSCC have been made, but OSTP intends to brief federal agencies before releasing details of its plans.

Kingsbury's role in the debate has been muted by the Justice Department investigation. He is accused of maintaining an association with Porton International plc., a British biotechnology company with offices in the United States.

Porton claims that Kingsbury was a scientific advisor to Porton subsidiary IGB Products, Ltd. The House of Representatives Committee on Space, Science and Technology got wind of the potential conflict last April, and asked the Reagan Administration to look into it. An investigation by Kingsbury's own agency was delivered to NSF Director Erich Bloch, who decided that "no immediate administrative action would be appropriate".

News of the investigation appeared in print for the first time last week, just as OSTP was planning to make its final decisions concerning the future of BSCC.

Kingsbury admits that he worked as a consultant to Porton, but says he suspended this relationship when he joined NSF. He also admits receiving stock in IGB Products while at NSF as part of his consulting arrangement, but says he returned the stock to the company. Porton officials confirm that Kingsbury has no current connection with the company. Joseph Palca 